\title{
Fossil micromammals of the early Pliocene locality of Almenara MB: biostratigraphical and palaeoecological implications
}

\author{
Samuel MANSINO ${ }^{1,2 *}$, Vicente Daniel CRESPO ${ }^{I, 2}$, María LAZZARO ${ }^{l}$, Francisco Javier RUIZ- \\ SÁNCHEZ ${ }^{1,2,3}$, Juan ABELLA $A^{3,4} \&$ Plinio MONTOYA ${ }^{1}$
}
${ }^{1}$ Departament de Geologia, Universitat de València, Doctor Moliner 50, 46100 Burjassot, Spain; samuel.mansino@uv.es; vicente.crespo@uv.es; marialazaro16@hotmail.com; francisco.ruiz@uv.es, juan.abella@gmail.com plinio.montoya@uv.es
${ }^{2}$ Museu Valencià d'Història Natural, L'Hort de Feliu, P.O. Box 8460, 46018 Alginet, Valencia, Spain
${ }^{3}$ INCYT-UPSE, Universidad Estatal Península de Santa Elena, 7047, Santa Elena, Ecuador
${ }^{4}$ Institut Català de Paleontologia Miquel Crusafont, Universitat Autònoma de Barcelona, Edifici ICTA-ICP, Carrer de les Columnes s/n, Campus de la UAB, Cerdanyola del Vallès, 08193 Barcelona, Spain
* Corresponding author

Mansino, S., Crespo, V.D., Lázaro, M., Ruiz-sánchez, F.J., Abella, J. \& Montoya, P. 2016. Fossil micromammals of the early Pliocene locality of Almenara MB: biostratigraphical and palaeoecological implications. [Micromamíferos fósiles de la localidad del Plioceno inferior de Almenara MB: implicaciones bioestratigráficas y paleoecológicas]. Spanish Journal of Palaeontology, 31 (2), 253-270.

\begin{abstract}
In this work, we have studied the fossil rodent, insectivore and chiropteran faunas, of a new locality from the AlmenaraCasablanca karstic complex, named ACB MB (Castellón, east Spain). We consider an early Ruscinian age for this site, close to the Miocene/Pliocene boundary, and infer warm and relatively humid conditions from the analysis of the micromammal assemblage. We remark the presence of two species of Eliomys in ACB MB, rare in localities of this age, and the lack of any gerbil remains, fossil markers of faunal interchanges between Africa and Europe in the context of the Messinian Salinity Crisis, recorded in the nearby late Miocene site of ACB M.
\end{abstract}

Keywords: Biostratigraphy, palaeoecology, Miocene/Pliocene boundary, micromammal, Spain.

\section{RESUMEN}

En este trabajo hemos estudiado los roedores, insectívoros y quirópteros fósiles de una nueva localidad del complejo kárstico de Almenara-Casablanca, denominada ACB MB (Castellón, Este de España). Consideramos que este yacimiento pertenece al Rusciniense temprano, cerca del límite Mio/Plioceno, e inferimos unas condiciones cálidas y relativamente húmedas a partir del análisis de su asociación de micromamíferos. Destacamos de la lista faunística de ACB MB la presencia poco frecuente de dos especies de Eliomys en yacimientos de esta edad, así como la ausencia de gerbílidos, marcadores del intercambio faunístico en el contexto de la Crisis de Salinidad Messiniense, y que se registran en el yacimiento cercano de ACB M (Mioceno tardío).

Palabras clave: Bioestratigrafía, paleoecología, límite Mioceno/Plioceno, micromamíferos, España. 


\section{INTRODUCTION}

The karstic complex of Almenara-Casablanca (ACB) is located in an abandoned quarry in the vicinity of the locality of Almenara (Castellón, Spain), in the eastern sector of the Iberian Range (Fig. 1). The fissure fillings containing vertebrate remains were discovered in the early 80s due to mining operations in the area, and in 1982 the Servei d'Investigacions Arqueològiques Provincials (SIAP) started a series of prospections, finding a great number of fossil remains (Furió et al., 2005). Initially, the finding of what seemed to be flint flakes in a Pleistocene level led the researchers to consider an anthropic origin for these localities. However, these accumulations were better explained by natural processes, and from 1986 on the excavations focused mainly on micropaleontology (Gusi, 2003; Furió et al., 2005).
Originally, the ACB complex comprised at least ten different sites, but some of them are buried under several meters of debris, since part of the area is now a dump (Gusi, 2003; Ruiz-Sánchez \& Montoya, 2009). The remaining sites comprise ACB M (late Miocene), ACB 1 (earliest Pleistocene), ACB 3 (upper early Pleistocene) and ACB 4 (late Pliocene) (Agustí et al., 2011).

In 2007, the group of vertebrate palaeontology of the Departament de Geologia of the Universitat de València started a new series of prospections to assess the degree of perturbation of the localities in this area, and to search for new fossiliferous levels (Ruiz-Sánchez \& Montoya, 2009). As a result, a new locality, probably situated in the same fissure infilling where ACB M is located, and therefore named ACB MB, was discovered (Fig. 2). The fossil remains of rodents, insectivores and chiropterans from this level are studied in this work, providing new data about the biostratigraphical and palaeoecological context of this fissure infilling.

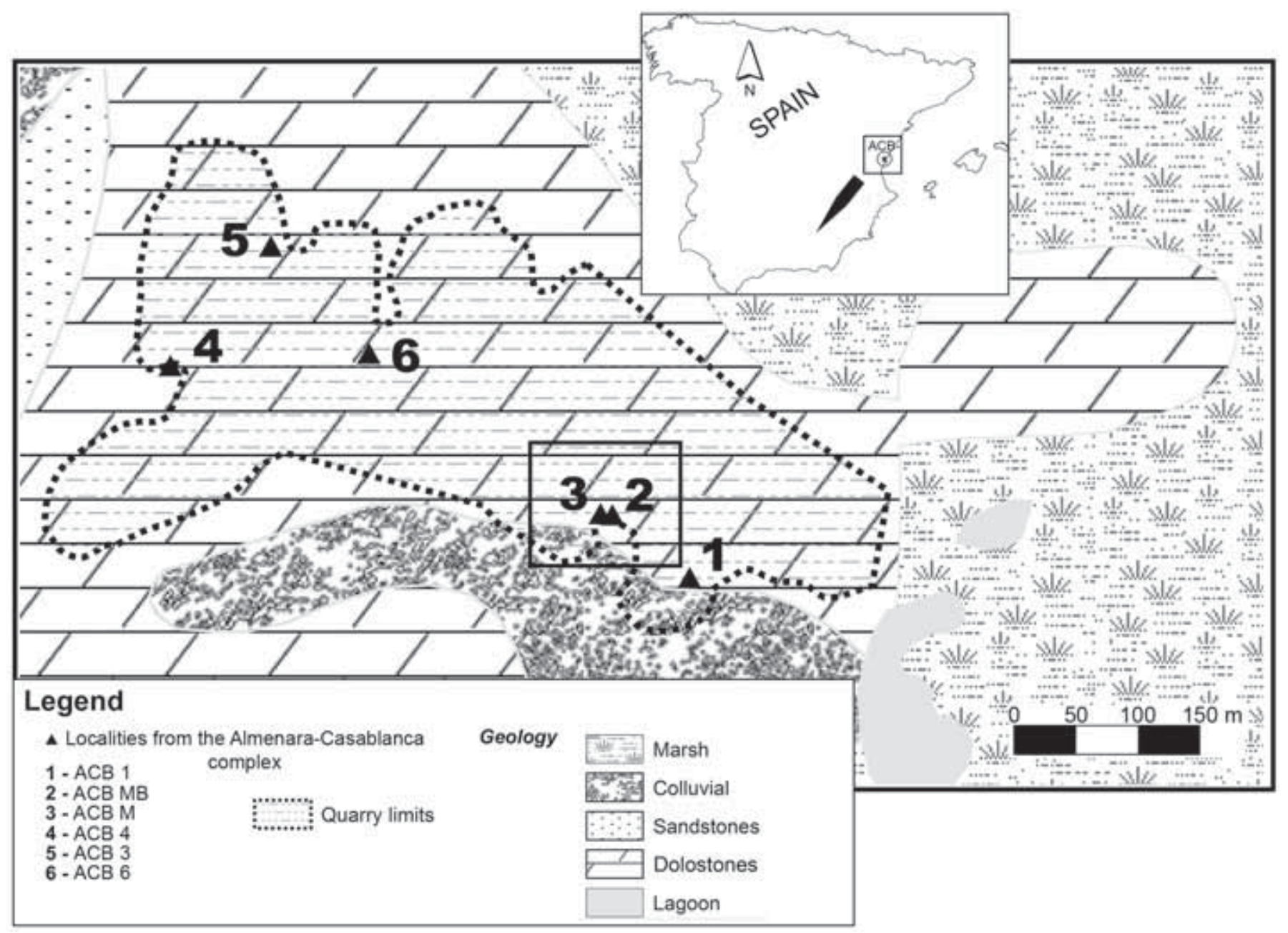

Figure 1. Geographical and geological setting of the Almenara-Casablanca complex, showing the location of the different sites found in the quarry. 

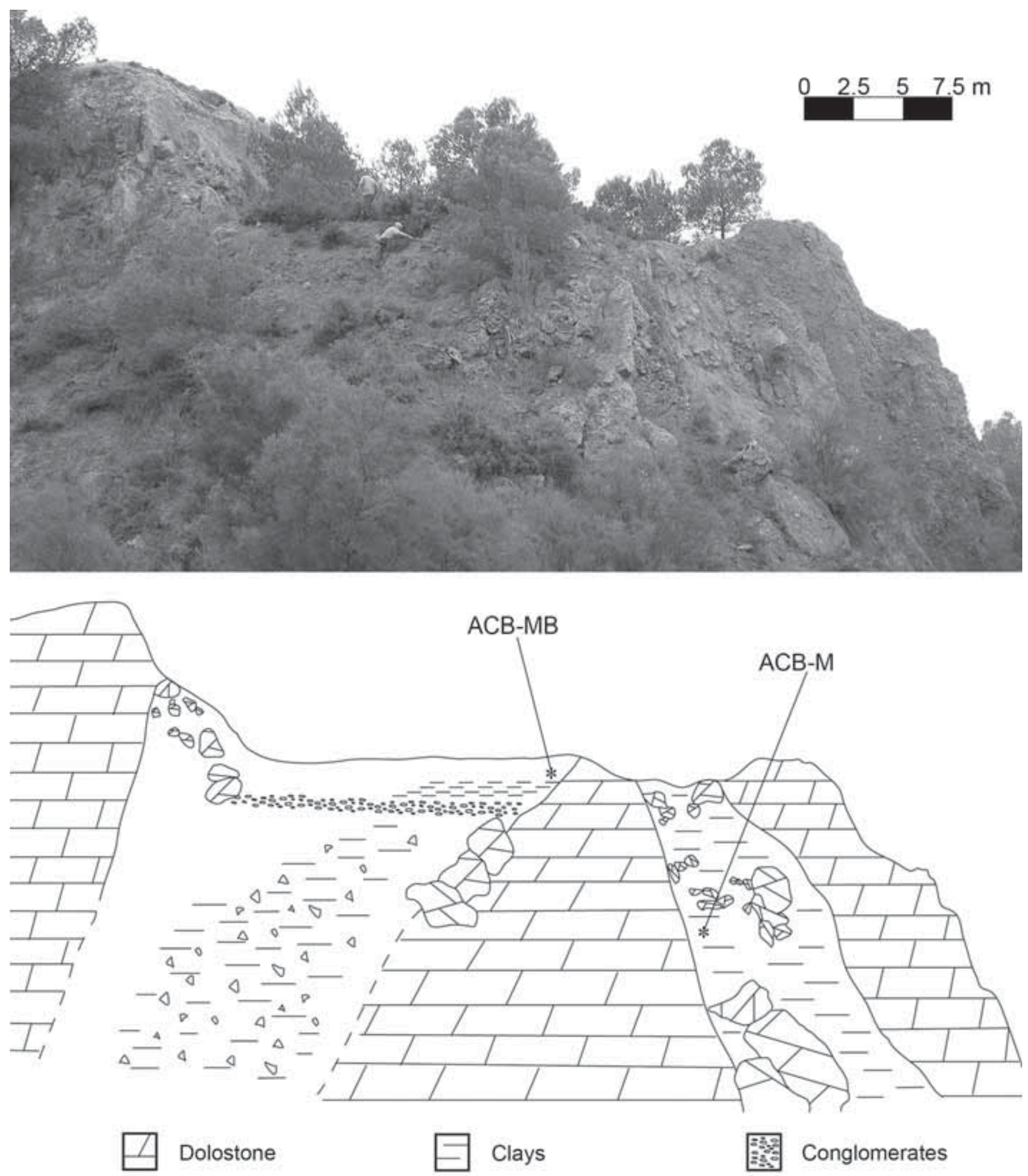

Figure 2. Detailed geological sketch of the fissure fillings containing the localities of ACB M (late Turolian) and ACB MB (early Ruscinian), showing their relative stratigraphic position. 


\section{MATERIALS AND METHODS}

In 2015 , we extracted $250 \mathrm{~kg}$ of sediment from the locality ACB MB. The study of this relatively small sample resulted in a micromammal collection comprising 93 identifiable remains, stored at the Museu de Geologia de la Universitat de València (MGUV) with the acronym ACBMB-.

The nomenclature and measurement methods are those from Martín-Suárez \& Freudenthal (1993) for the family Muridae, Mein \& Freudenthal (1971) for the Cricetidae, Daams (1981) and Freudenthal (2004) for the Gliridae, Sevilla (1988) for the Chiroptera, and Reumer (1984) for the insectivores. Measurements are in millimetres and were taken on a Leica MZ75 binocular microscope, by means of displacement of a mechanical stage, connected to a Sony Magnescale measuring equipment.

Abbreviations. AC, Alcoi Cristian; ACB, Almenara Casablanca; AL2, Alcoi 2; AW, anterior width; BL, buccal length; I, upper incisive; c, lower canine; $\mathbf{C}$, upper canine; p, lower premolar; $\mathbf{P}$, upper premolar; $\mathbf{m}$, lower molar; $\mathbf{M}$, upper molar; $\mathbf{H}$, height; $\mathbf{L}$, length; $\mathbf{L L}$, lingual length; LT, length of the talon; PE, posterior emargination; PW, posterior width; Taw, talonid width; Trw, trigonid width.

\section{SYSTEMATIC PALAEONTOLOGY}

Order RODENTIA Bowdich, 1821

Family Muridae Illiger, 1811

Genus Occitanomys Michaux, 1969

Type species Occitanomys brailloni Michaux, 1969

Occitanomys alcalai Adrover et al., 1988

(Figs 3a-b)

Material. $2 \mathrm{~m} 1$ (ACBMB-105, ACBMB-110), 3 m2 (ACBMB-29, АCBMB-30, АСВMB-103), 3 m3 (ACBMB-38, ACBMB-39, ACBMB-108), 1 M1 (ACBMB-99), 1 M2 (ACBMB-102), 3 M3 (ACBMB-20, ACBMB-26, ACBMB-104).

Measurements. Table 1.

\section{Description.}

m1. Both specimens are broken and poorly preserved. One of the molars has a reduced longitudinal spur. The other specimen shows a well-developed c1 and two accessory cuspids. The posterior heel is large, oval and lingually displaced. Roots are not preserved.

m2. Large and isolated anterolabial cuspid. One specimen (Fig. 3a) has a hint of distal spur. The labial cingulum is wide, but there is neither $\mathrm{c} 1$ nor accessory cuspids. The posterior heel is small and oval. There are two roots.
Table 1. Measurements in millimetres of the teeth of Occitanomys alcalai from ACB MB. $\mathrm{m} 1$ = first lower molar; m2 $=$ second lower molar; $\mathrm{m} 3=$ third lower molar; $\mathrm{M} 1$ = first upper molar; $\mathrm{M} 2$ = second upper molar; $\mathrm{M} 3=$ third upper molar.

\begin{tabular}{cccccc}
\hline Element & Parameter & $\begin{array}{c}\mathbf{N}^{\mathbf{0}} \text { of } \\
\text { elements }\end{array}$ & minimum & mean & maximum \\
\hline m2 & Length & 3 & 1.20 & 1.28 & 1.33 \\
& Width & 2 & 1.12 & 1.15 & 1.18 \\
m3 & Length & 3 & 1.03 & 1.10 & 1.19 \\
& Width & 1 & 0.93 & 1.02 & 1.13 \\
M1 & Width & 1 & - & 1.33 & - \\
M2 & Length & 1 & - & 1.32 & - \\
M3 & Length & 1 & - & 1.01 & - \\
& Width & 1 & 0.97 & 1.00 & 1.03
\end{tabular}

m3. The anterolabial cuspid is small in one specimen and absent in the other two. One molar has a weak connection between the posterior complex and the protoconid-metaconid pair, which is absent in the others. Roots are not preserved.

M1. The molar is broken anteriorly. The t1-t5 connection is high. There is a well-developed $t 1$ bis. There is a distal spur on $\mathrm{t} 3$. Roots are not preserved.

M2. The specimen is broken anterolabially and much worn. There is a large $\mathrm{t} 1$ bis. The $\mathrm{t} 1$ is basally connected to the $\mathrm{t} 5$. The $\mathrm{t} 3$ is reduced. Roots are not preserved.

M3. The $\mathrm{t} 1$ is isolated. The $\mathrm{t} 3 \mathrm{is}$ absent. The $\mathrm{t} 4$, $\mathrm{t} 5$ and t6 are connected, and in one specimen both $\mathrm{t} 4$ and t6 are connected to t8. Roots are not preserved.

Remarks. The relatively high crown, well-developed t1 bis in M1, absence of isolated cusps in the upper molars and lack of complete longitudinal crests in the lower molars are typical traits of Occitanomys alcalai. The size of these specimens is similar to that of $O$. alcalai from its type locality, Peralejos E (Adrover et al., 1988), and other localities from the Teruel Basin such as La Gloria 4 and 5, Celadas 9, Valdecebro 3 and 6 and Villastar (Adrover et al., 1993), as well as the localities from the Granada (García-Alix et al., 2008a) and Guadix basins (MinwerBarakat et al., 2009a, 2009b).

The teeth from ACB MB are slightly smaller, have less developed connections in the lower molars and more developed connections in the upper molars than Occitanomys adroveri (Thaler, 1966). These specimens are much smaller and with less developed spurs and crests in the upper molars than O. brailloni Michaux, 1969. Our material is also larger and show a greater development of the $\mathrm{t} 1 \mathrm{bis}$ and less developed longitudinal crests in the lower molars than O. sondaari van de Weerd, 1976.

Genus Paraethomys Petter, 1968

Type species Paraethomys filfilae Petter, 1968 
Paraethomys meini (Michaux, 1969)

(Figs 3c-d)

Material. $2 \mathrm{~m} 2$ (ACBMB-33, ACBMB-35), 3 m3 (ACBMB-40, ACBMB-42, ACBMB-107), 5 M1 (ACBMB-1, АСBMB-2, АСВMB-7, АСВMB-12, ACBMB-14), 1 M2 (ACBMB-17), 1 M3 (ACBMB-21).

Measurements. Table 2.

Table 2. Measurements in millimetres of the teeth of Paraethomys meini from ACB MB. $\mathrm{m} 1$ = first lower molar; $\mathrm{m} 2=$ second lower molar; $\mathrm{m} 3$ = third lower molar; $\mathrm{M} 1=$ first upper molar; M2 = second upper molar; M3 = third upper molar.

\begin{tabular}{cccccc}
\hline Element & Parameter & $\begin{array}{c}\mathbf{N}^{\mathbf{0}} \text { of } \\
\text { elements }\end{array}$ & minimum & mean & maximum \\
\hline \multirow{2}{*}{ m2 } & Length & 2 & 1.47 & 1.53 & 1.59 \\
& Width & 2 & 1.40 & 1.42 & 1.43 \\
m3 & Length & 3 & 1.17 & 1.22 & 1.26 \\
& Width & 3 & 1.10 & 1.12 & 1.14 \\
M1 & Length & 2 & 2.13 & 2.22 & 2.31 \\
& Width & 5 & 1.41 & 1.50 & 1.60 \\
M2 & Length & 1 & - & 1.69 & - \\
& Width & 1 & - & 1.55 & - \\
M3 & Length & 1 & - & 1.08 & - \\
& Width & 1 & - & 1.18 & -
\end{tabular}

\section{Description.}

$\mathbf{m} 2$. The anterolabial cuspid is large and isolated. There is no longitudinal crest. The labial cingulum is moderate, bearing a large $\mathrm{c} 1$ but no accessory cuspids. Medium-sized oval posterior heel. There are two roots.

$\mathbf{m 3}$. The anterolabial cuspid is absent in one specimen and small in the other two. There is no longitudinal connection. There is neither $\mathrm{cl}$ nor accessory cusps. Roots are not preserved.

M1. The t1-t2 connection is low. There are reduced spurs on $\mathrm{t} 1$ in three out of five specimens. There is no trace of spur on the $\mathrm{t} 3$ in two molars, a hint of spur in another two (Fig. 3c), and more developed spurs in the remaining two specimens. The connection between $\mathrm{t} 4$ and $\mathrm{t} 8$ is low. There is a small t12. Roots are not preserved.

M2. The $\mathrm{t} 1$ and $\mathrm{t} 3$ are isolated. The $\mathrm{t} 9$ is reduced to a thickening of the enamel (Fig. 3d). There is no t12. Roots are not preserved.

M3. The $\mathrm{t} 1$ is isolated. The $\mathrm{t} 4, \mathrm{t} 5, \mathrm{t} 6$ and $\mathrm{t} 8$ are connected. Roots are not preserved.

Remarks. The specimens from ACB MB show some of the typical traits of Paraethomys: moderate or reduced labial cingulum in the lower molars, reduced or absent anterolabial cusp in $\mathrm{m} 3$ and reduced or absent $\mathrm{t} 9$ in M2 (Fig. 3d).
The molars from ACB MB are clearly smaller than the Pliocene Paraethomys such as $P$. jaegeri Montenat \& de Bruijn, 1976, P. abaigari Adrover et al. 1988 and P. aff. abaigari, and consistent in size with other populations of P. meini such as Crevillente 6 (de Bruijn et al., 1975), Peralejos E (Adrover et al., 1988), the localities from the Granada Basin (García-Alix et al., 2008a) and Venta del Moro (Mansino, personal observation). However, the two larger M1 from ACB MB show spurs on both $\mathrm{t} 1$ and $\mathrm{t}$. These spurs are usually more developed in the Pliocene species of the genus, and the width of these specimens, the only measurement that we were able to make, is close to that of the smaller M1 of Paraethomys aff. abaigari, such as some molars from AC-0 (Mansino et al., 2015a) and La Gloria 4 (Adrover et al., 1993). In this regard, the sample from ACB MB resembles some Paraethomys populations close in age to the Mio/Pliocene boundary, in which a great biometrical variability has been described, although the presence of two distinct Paraethomys species in these assemblages is unlikely (García-Alix et al., 2008a; Mansino et al., in press).

Genus Stephanomys Schaub, 1938

Type species Mus donnezani Depéret, 1890

$$
\text { Stephanomys dubari Aguilar et al., } 1991
$$

(Figs 3e-g)

Material. $3 \mathrm{~m} 1$ (ACBMB-27, ACBMB-28, ACBMB-100), $4 \mathrm{~m} 2$ (ACBMB-31, АCBMB-32, АСВМB-34, АСВМВ-36), $3 \mathrm{~m} 3$ (АСВMB-41, ACBMB-106, ACBMB-109), 10 M1 (ACBMB-3 to ACBMB-6, ACBMB-8 to ACBMB-11, ACBMB-13, АCBMB-15), 6 M2 (АСBMB-16, АСВMB-18, ACBMB-19, ACBMB-37, ACBMB-101, ACBMB-111), 4 M3 (ACBMB-22 to ACBMB-25).

\section{Measurements. Table 3}

\section{Description.}

m1. The anteroconid is connected to the protoconidmetaconid pair. There is a well-developed longitudinal crest. The labial cingulum is moderate. There is a mediumsized c1, but no accessory cuspids. The posterior heel is oval. Roots are not preserved.

m2. The anterolabial cuspid is large and isolated. The anterior complex is connected to the metaconid or to the protoconid-metaconid junction by a longitudinal crest. The $\mathrm{c} 1$ is small or absent. The posterior heel is oval. There are two roots.

m3. The anterolabial cuspid is large. The longitudinal crest is low in two specimens, and another one has a spur. These longitudinal connections arise from the metaconid. A small $\mathrm{c} 1$ is present in one specimen. There are two roots. 


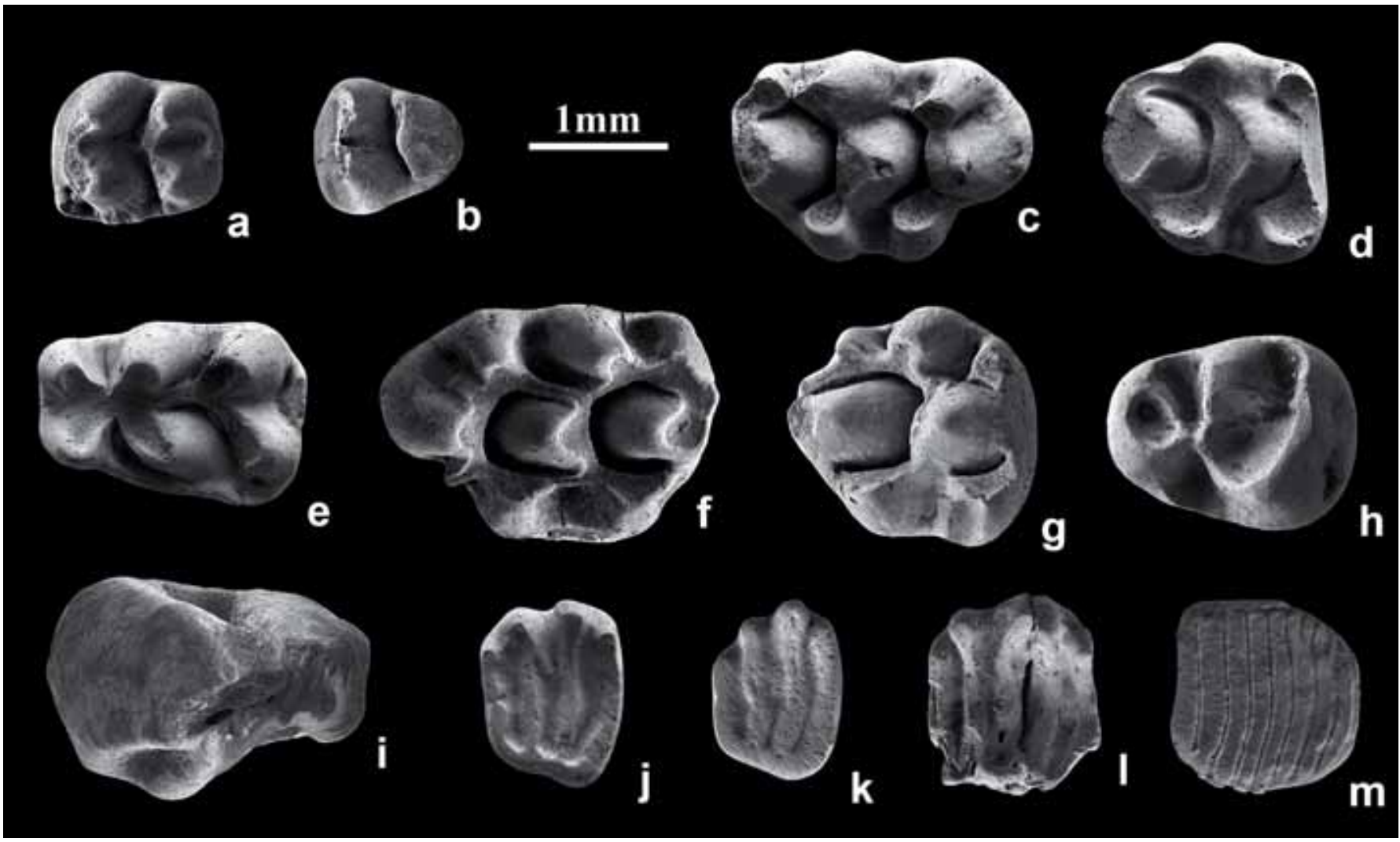

Figure 3. Rodents from ACB MB. Occitanomys alcalai, a) left m2, ACBMB-29; b) left m3, ACBMB-38. Paraethomys meini, c) right M1, ACBMB-7; d) right M2, ACBMB-17. Stephanomys dubari, e) left m1, ACBMB-27; f) left M1, ACBMB-3; g) right M2, ACBMB-16. Apocricetus sp., h) right M3, ACBMB-43. Ruscinomys cf. schaubi, i) left m3, ACBMB-44. Eliomys truci, j) right m2, ACBMB-50. k) right M1, M2, ACBMB-47; Eliomys sp., l) right M3, ACBMB-48. Muscardinus cf. vireti, m) right $\mathrm{M} 1, \mathrm{M} 2$, ACBMB-49. Scale bar $1 \mathrm{~mm}$.

Table 3. Measurements in millimetres of the teeth of Stephanomys dubari from ACB MB. $\mathrm{m} 1$ = first lower molar; $\mathrm{m} 2$ $=$ second lower molar; $\mathrm{m} 3=$ third lower molar; $\mathrm{M} 1$ = first upper molar; M2 = second upper molar; M3 = third upper molar.

\begin{tabular}{cccccc}
\hline Element & Parameter & $\begin{array}{c}\mathbf{N}^{\mathbf{0}} \text { of } \\
\text { elements }\end{array}$ & minimum & mean & maximum \\
\hline m1 & Length & 2 & 2.05 & 2.13 & 2.21 \\
& Width & 2 & 1.27 & 1.34 & 1.45 \\
m2 & Length & 3 & 1.54 & 1.61 & 1.69 \\
& Width & 3 & 1.54 & 1.57 & 1.59 \\
m3 & Length & 3 & 1.34 & 1.35 & 1.36 \\
& Width & 3 & 1.20 & 1.22 & 1.23 \\
M1 & Length & 8 & 2.33 & 2.40 & 2.50 \\
& Width & 8 & 1.65 & 1.72 & 1.78 \\
M2 & Length & 4 & 1.64 & 1.70 & 1.78 \\
& Width & 4 & 1.65 & 1.70 & 1.77 \\
M3 & Length & 1 & 1.17 & 1.22 & 1.25 \\
& Width & 1 & 1.13 & 1.16 & 1.19
\end{tabular}

M1. The t1 is displaced slightly backwards with respect to the $\mathrm{t} 3$. The $\mathrm{t} 1$ bis is well developed, while the $\mathrm{t} 2$ bis is smaller. The $\mathrm{t} 1$ and $\mathrm{t} 3$ are connected to the $\mathrm{t} 5$ by longitudinal crests, being the labial crest usually higher. The t4-t5-t6-t8-t 9 are connected by high crests. There is a small t12. There are three roots.

M2. The $\mathrm{t} 1$ is large, and a small $\mathrm{t} 1 \mathrm{bis}$ is attached to its posterior side. The connection between $\mathrm{t} 1$ and $\mathrm{t} 5$ is very low (Fig. 3g). The $\mathrm{t} 3$ is isolated, although in one there is a very low crest connecting $t 3$ and $t 5$. The $t 4, t 5$, t 6 and t9 are connected by high crests. There is a much-reduced t12. There are three roots.

M3. The $t 1, t 4, t 5$ and $t 6$ are connected. There is no t3. In three specimens, a spur arises from the 8 directed towards the t6, and in another one these cusps are connected by a crest. There are two roots.

Remarks. The height of the crown, development of longitudinal crests in the lower molars and distal crests or spurs on the $\mathrm{t} 1$ and $\mathrm{t} 3$ of the upper molars suggest that these specimens belong to the genus Stephanomys. These molars are smaller, less hypsodont and with a less pronounced stephanodonty than the Stephanomys identified 
in the Pliocene and Pleistocene (see Minwer-Barakat et al., 2011, and references therein).

Stephanomys dubari belongs to the anagenetic lineage Occitanomys adroveri-Stephanomys ramblensis van de Weerd 1976-Stephanomys dubari-Stephanomys cordii Ruiz-Bustos, 1986, in which there is a progressive increase in size and stephanodonty along time (García-Alix et al., 2008a). The specimens from ACB MB are larger, more hypsodont and with a more pronounced stephanodonty than $S$. ramblensis, in which the longitudinal crest of the $\mathrm{m} 1$ is sometimes directed to the protoconid, and the $\mathrm{t} 1$ and $\mathrm{t} 3$ of the $\mathrm{M} 1$ and $\mathrm{M} 2$ rarely develop full longitudinal crests (García-Alix, 2006; García-Alix et al., 2008a). These molars are smaller and have less developed longitudinal connections in M1 and M2 than S. cordii from AL2-C and AL2-D (Mansino et al., 2013) and Stephanomys aff. cordii from AC-0 (Mansino et al., 2015a). The longitudinal connection of $\mathrm{m} 3$ usually arises from the metaconid in $S$. dubari, as in the specimens from ACB MB, while in $S$. cordii this crest arises from the protoconid (Cordy, 1976).

In Stephanomys dubari the $\mathrm{t} 1$ is displaced slightly more backwards than in $S$. cordii. However, in the specimens from ACB MB this cusp is close to the position of the t3 except in three molars. Despite this, because of their size and development of the longitudinal connections, we ascribe the material from ACB MB to $S$. dubari.

Family Cricetidae Fischer, 1817

Subfamily Cricetodontinae Stehlin \& Schaub, 1951

Genus Apocricetus Freudenthal et al., 1998

Type species Cricetus angustidens Depéret, 1890

Apocricetus sp.

(Fig. 3h)

Material. 1 M3 (ACBMB-43).

Measurements. M3: $\mathrm{L}=1.75 \times \mathrm{W}=1.44$.

Description. Moderately developed lingual anteroloph. The protocone is not separated from the lingual border. The labial anteroloph is long and connected to the paracone. The anterior protolophule, posterior protolophule and anterior metalophule are complete, but the anterior protolophule is lower than these other two crests (Fig. 3h). The posterolingual corner is rounded. The posterosinus is reduced. Roots are not preserved.

Remarks. Traditionally, size has been the main criterion to distinguish between the different species of the genus Apocricetus (Freudenthal et al., 1998), although it is indeed the quantification of the morphological characters the best way to discern between them (Mansino et al., 2014; RuizSánchez et al., 2014). The size of the only M3 from ACB MB is consistent with the largest specimens of $A$. plinii
(Freudenthal et al., 1991) and $A$. alberti Freudenthal et al. 1998, and with the smallest M3 of $A$. barrierei (Mein \& Michaux, 1970). This molar is larger than Apocricetus aff. plinii, and much smaller than $A$. angustidens (Depéret, 1890) (Freudenthal et al., 1998; García-Alix et al., 2008b; Mansino et al., 2014; Ruiz-Sánchez et al., 2014).

In the M3 of Apocricetus, the most diagnostic character is the proportion of presence/absence of the anterior protolophule. This crest is more frequent in A. plinii and A. alberti than in $A$. barrierei, but it is also relatively common in this latter species (Mansino et al., 2014; RuizSánchez et al., 2014). The presence of just one specimen precludes assigning it to any particular species until more material becomes available. Thus, we assign this molar to Apocricetus sp.

Genus Ruscinomys Depéret, 1890

Type species Ruscinomys europaeus Depéret, 1890

Ruscinomys cf. schaubi Villalta \& Crusafont Pairó, 1956 (Fig. 3i)

Material. 1 M3 (ACBMB-44).

Measurements. M3: $\mathrm{L}=2.28 \times \mathrm{W}=1.63 \times \mathrm{H}: 2.67$.

Description. The molar has two lobes, delimited by sinus and mesosinus, being the anterior lobe larger. Roots are not preserved.

Remarks. The general morphology and great hypsodonty of the specimen suggest that it belongs to the genus Ruscinomys. However, the M3 lack most of the diagnostic features that allow distinguishing between the different species of the genus.

The size of the molar agrees with the largest specimens of R. schaubi from Los Mansuetos (Adrover, 1969) and Aljezar B (Adrover, 1986), being larger than R. lasallei Adrover, 1969, from Alcoy, and smaller than R. europaeus Depéret, 1890 from Nîmes (Adrover, 1969). The M3 of $R$. schaubi is less reduced and more similar to the M2 than in R. lasallei (Adrover, 1969). Since the posterior lobe of the specimen from ACB MB is well developed, we ascribe this specimen to Ruscinomys cf. schaubi.

Family Gliridae Muirhead, 1819

Subfamily Dryomyinae de Bruijn, 1967

Genus Eliomys Wagner, 1840

Type species Eliomys melanurus Wagner, 1840

Eliomys truci Mein \& Michaux, 1970

(Figs 3j-k)

Material. $1 \mathrm{p} 4$ (ACBMB-45), $1 \mathrm{~m} 1$ (ACBMB-46), 1 M1/2 (ACBMB-47), 1 M3 (ACBMB-48). 
Measurements. $\mathrm{p} 4$ : $\mathrm{L}=1.20 \mathrm{x} \mathrm{W}=1.06 ; \mathrm{m} 1: \mathrm{L}=1.26 \mathrm{x}$ $\mathrm{W}=1.29 ; \mathrm{M} 1 / 2: \mathrm{L}=1.05 \times \mathrm{W}=1.32 ; \mathrm{M} 3: \mathrm{L}=0.98 \times \mathrm{W}=1.25$.

\section{Description.}

p4. Subtriangular outline. The protoconid and the large anterolophid create a high, triangular anterior complex, which is separated from the metaconid by a narrow furrow. There is a long centrolophid, which almost reaches the protoconid. The mesoconid and entoconid are connected by the mesolophid, and separated from the anterior complex by a deep valley. The mesoconid and hypoconid are separated. There is a discontinuous posterotropid. The posterolophid is high and curved. Roots are not preserved.

m1. Rectangular outline. The anterolophid is connected to the protoconid. Metalophid and metaconid are connected basally. The centrolophid is long and not connected to the metalophid. There is a long posterotropid. The hypoconid is large. Roots are not preserved.

M1/2. Trapezoidal outline. The anteroloph is connected to the protocone. The paracone and metacone are high and separated. Straight protoloph and metaloph. The precentroloph is absent, but there is a short postcentroloph (Fig. 3j). The posteroloph is discontinuous, and connected to the endoloph. Roots are not preserved.

M3. Trapezoidal outline. The anteroloph is connected to the protocone. The paracone and metacone are high and separated. The protoloph and metaloph are slightly sinuous (Fig. 3k). Both centrolophs are absent. There is a continuous endoloph. Roots are not preserved.

Remarks. The molars from ACB MB agree in size with E. truci and the smaller specimens of E. yevesi Mansino et al., 2014, being larger than the other Miocene representatives of the genus: E. lafarguei Aguilar et al., 2007, E. assimilis Mayr, 1979 and E. reductus Mayr, 1979. The teeth from ACB MB are clearly smaller than those of the Pliocene form E. intermedius Friant, 1953, and those of the Pleistocene and extant E. quercinus (Linnaeus, 1766) (see Mansino et al., 2015b).

The presence of a long centrolophid and a long posterotropid in the lower molars and absent or reduced centrolophs in the upper molars also agrees with Eliomys truci. The shape of these teeth is more quadrangular than those of E. reductus and E. assimilis; they further differ from $E$. assimilis by the absence of accessory crests in the upper molars, and from E. reductus by the presence of posterotropid and a discontinuous endolophid. The specimens from ACB MB have a longer centrolophid than E. lafarguei, which also has a continuous endolophid, and less developed centrolophs in the upper molars than $E$. yevesi, E. intermedius and E. quercinus.

\section{Eliomys sp}

(Fig. 31)

\section{Material. 1 M1/2 (ACBMB-49).}

Measurements. M1/2: $\mathrm{L}=1.26$.

Description. Molar broken lingually. The anteroloph is separated from the paracone and protoloph. The paracone and metacone are high and separated. The protoloph and metaloph are continuous and slightly sinuous. There is a well-developed precentroloph (Fig. 31), connected to the metacone.

Remarks. This specimen is clearly larger, more concave and has a longer precentroloph than the other molars of Eliomys from ACB MB (see Figs 3j-k, 31). Its size is consistent with the smaller specimens of $E$. intermedius and the larger ones of E. yevesi (Mansino et al., 2015b), and the long precentroloph is more common in these species than in E. truci (Adrover, 1986; García-Alix et al., 2008b; Mansino et al., 2015b). However, this molar is smaller than the specimens of Eliomys aff. intermedius from ACB 4 (Gil \& Sesé, 1985).

Mansino et al. (2015b) defined the lineage E. truci-E. yevesi-E. intermedius-E. quercinus, in which there is a trend towards the development of centrolophs in the upper molars, and a reduction of the accessory crests in the lower molars. These authors explained the presence of two different species of Eliomys in a number of Pliocene localities such a Villalba Alta, Séte, Orrios 3 (Adrover, 1986), La Gloria 4 (Adrover et al., 1988) and TCH-13 (García-Alix et al., 2008b), by a process of cladogenesis near the Mio/Pliocene boundary, following the previous works by Adrover (1986) and García-Alix et al. (2008b). These localities have yielded material of a small Eliomys, E. truci, and a much larger one, E. intermedius. However, the scarce material available of the larger form in ACB MB does not allow a specific ascription, since its size and morphology fall within the variability of both $E$. yevesi and E. intermedius.

Subfamily Glirinae Thomas, 1897

Genus Muscardinus Kaup, 1829

Type species Mus avellanarius Linnaeus, 1758

Muscardinus cf. vireti Hugueney \& Mein, 1965

(Fig. 3m)

Material. 1 M2 (ACBMB-50).

Measurements. M2: L>1.32 x W>1.36.

Description. Digested specimen; it lacks the enamel of the lingual and posterior sides. The outline is subquadrangular. There are eight low ridges, slightly concave towards the posterior side of the molar except the first one, which is straight. Both the sixth and the seventh 
ridges bifurcate near the labial border, creating two small extra ridges (Fig. $3 \mathrm{~m}$ ). Roots are not preserved.

Remarks. The extremely flat occlusal outline and high number of ridges are characteristic of Muscardinus. There are six species of Muscardinus that have eight ridges in the M2: M. sansaniensis (Lartet, 1851), M. aff. sansaniensis, M. vallesiensis Hartenberger, 1967, M. vireti Hugueney \& Mein, 1965, M. helleri Fejfar \& Storch, 1990 and M. meridionalis García-Alix et al., 2008c.

The size of the specimen is consistent with $M$. meridionalis and $M$. vireti, being smaller than $M$. vallesiensis and $M$. helleri, and larger than $M$. sansaniensis (data from García-Alix et al., 2008c). The presence of extra ridges in M2 differs from $M$. helleri and $M$. meridionalis (García-Alix et al., 2008c; Colombero et al., 2014). Therefore, we assign the M2 from ACB MB to Muscardinus cf. vireti.

Family Sciuridae Fischer, 1817

Subfamily Pteromyinae Brandt, 1855

Genus Heteroxerus Stehlin \& Schaub, 1951

Type species Xerus grivensis Forsyth Major, 1893

\section{Heteroxerus sp.}

Material. $1 \mathrm{~m} 2$ (ACBMB-51).

Description. The specimen is broken lingually. There is a well-developed anterior cingulum, which bears a double anteroconulid. The protoconid and hypoconid are large and high, and connected to the mesoconid by low crests. Roots are not preserved.

Remarks. The small size and well-developed labial cingulum of the specimen are typical traits of Heteroxerus, differing from the genus Atlantoxerus (Cuenca-Bescós, 1988). However, the scarcity and poor state of preservation of this molar prevents us from reaching a specific ascription.

Order CHIROPTERA Blumenbach, 1779

Suborder Microchiroptera Dobson, 1875

Family Vespertilionidae Gray, 1821

Genus Myotis Kaup, 1829

Type species Vespertilio myotis Borkhausen, 1797

Myotis sp.

(Figs 4a-d)

Material. $1 \mathrm{c}$ (ACBMB-77), $1 \mathrm{~m} 1$ (ACBMB-61), $1 \mathrm{~m} 2$ (ACBMB-85), 1 C (ACBMB 73), 1 M1 (ACBMB-62), 1 M2 (ACBMB-63).
Measurements. c: $\mathrm{L}=1.13 \times \mathrm{W}=0.99$; $\mathrm{m} 1$ : $\mathrm{Trw}=1.38$; C: $\mathrm{L}=1.20 \times \mathrm{W}=1.05 ; \mathrm{M} 2: \mathrm{L}=1.71 \times \mathrm{W}=1.92$.

\section{Description.}

c. Subelliptical tooth. There is a narrow lingual cingulum and a wide labial cingulum that reaches the posterior side of the molar (Fig. 4a). The cingulum bears a small cuspid on its posterolabial side, which encloses a small valley. Roots are not preserved.

$\mathbf{m 1}$. This molar is broken labially. There is a ' $\mathrm{V}$ ' shaped paralophid. The protoconid is the highest cusp of the trigonid. The paraconid, the metaconid and the entoconid are aligned in occlusal view. The entocristid is convex on its anterior side, and concave on its posterior side. The labial cingulum is broken posteriorly. The lingual cingulum is absent. Roots are not preserved.

m2. The trigonid is the only cusp preserved. The morphology is similar to that of the $\mathrm{m} 1$, but this element is narrower. Roots are not preserved.

C. Teeth rounded in cross section. The cingulum borders the main cusp (Fig. 4b). The labial side of this cingulum is wide. There is one well-developed root.

M1. Subquadrangular tooth. The parastyle is broken. The anterior cingulum is narrow and connected to the protocone. Another cingulum is present on the anterior side of the protocone. The labial cingulum of the paraflex is small and the labial cingulum of the metaflex is better developed. The metacone is slightly higher than the paracone. The ectoloph is very symmetric. The mesostyle is narrow. The paraloph, metaloph and paraconule are small. There is a short postprotocrista. Both the talon and hypocone are absent. The cingulum of the talon is wide (Fig. 4c). The distal cingulum is labially connected to the metastyle. Roots are not preserved.

M2. The M2 is similar to the M1, but the parastyle is more developed (Fig. 4d). The anterior cingulum of the protocone is wider than in the M1. The labial cingulum of the paraflex is smaller. The ectoloph is less asymmetric than in the M1. The paraloph is absent, and the distal cingulum is not connected to the metastyle on the labial side. Roots are not preserved.

Remarks. The presence of metaloph in the upper molars and a paraloph and a small paraconule in M1 are characteristic of the genus Myotis. These teeth differ from the similar genus Leuconoe by not having a well-developed paraconule (Ziegler, 2000, 2003).

The presence of both metaloph and paraloph in the specimens from ACB MB differs from Myotis myotis (Borkhausen, 1797), Myotis blythi (Tomes, 1857), Myotis nattereri (Kuhl, 1817), Myotis intermedius Ziegler, 2000 and Myotis darelbeidensis Gunnell et al., 2011 (Ziegler, 2000; Gunnell et al., 2011). Myotis elegans Baudelot, 1972 differs from our specimens by its high and more anterior protocone, while in Myotis boyeri Mein, 1965 
the postprotocrista joins the posterior cingulum (Sevilla $\&$ Chaline, 2004).

The teeth of Myotis minor Ziegler, 2000 is smaller than our material, and has well-developed metaloph and paraloph in the M2 and a complete lingual cingulum (Ziegler, 2000). Meanwhile, Myotis korotkevichae Rosina \& Semenov, 2012 differs from the teeth from ACB MB by its M2 with hyperdeveloped metaloph and paraloph (Rosina \& Semenov, 2012).

Although the metaloph is poorly developed and the paraloph resembles Myotis bavaricus Ziegler, 2003, the absence of the paraconule in this species differs from our specimens. The presence of a paraconule in the M1 from ACB MB disagrees with Myotis mystacinus (Kuhl, 1817) (Galán et al., in press). Myotis reductus Ziegler 2003 differs from our material since the metaloph, paraloph, metaconule and paraconule, are missing, and thus showing a complete lingual cingulum. The upper molars of Myotis bechsteini (Kuhl, 1817) have weak traces of paralophes but no metalophes (Rosina \& Kruskop, 2011). Finally, Myotis emarginatus (Geoffroy, 1806) differs from the studied specimens by having a metaconule, which is well developed in the M2 (Popov, 2004).

The remains from ACB MB are morphologically similar to the extant Myotis daubentonii (Kuhl, 1817) and Myotis brandtii (Eversmann, 1845), although they differ from these species by the presence of a small paraloph, metaloph and paraconule (Sevilla \& Chaline 2004). These authors designate Myotis delicatus Heller, 1936 as a probably Plio/Pleistocene ancestor of both species, but Ziegler (2003) placed this species in the genus Leuconoe. Another similar species is the Pliocene Myotis podlesicensis Kowalski, 1956, because it has both metaloph and paraloph (Rosina \& Kruskop, 2011). The lack of more diagnostic characters prevents a specific ascription, but we consider the specimens from ACB MB to be related to the extant species $M$. daubentonii and $M$. brandti, and to the Pliocene species M. podlesicensis.

Genus Miniopterus Bonaparte, 1837

Type species Vespertilio schreibersii Kuhl, 1817

Miniopterus fossilis Zapfe, 1950

(Figs 4e-i)

Material. 1 p3 (ACBMB-83), $1 \mathrm{~m} 1$ (ACBMB-52), $1 \mathrm{~m} 2$ (ACBMB-53), 1 M1 (ACBMB-55), 1 M3 (ACBMB-54).

Measurements. p3: $\mathrm{L}=0.96 \times \mathrm{W}=0.84 ; \mathrm{m} 1$ : $\mathrm{L}=1.43$ x Trw $=0.87$ x Taw $=0.91 ; \mathrm{m} 2: \mathrm{L}=1.37 \times$ Trw $=0.96 \times$ Taw $=0.95 ; \mathrm{M} 3=1.37 \times 1.69$.

\section{Description.}

p3. Rectangular shape. Two edges are present in the cusp, the lingual edge more developed than the labial one, and three facets. The labial side is more developed. The posterior part of the tooth is wider than anterior one. The cingulum is well developed, and irregular on its lingual side. A small cuspule is present in both the anterolingual and the posterolingual sides. There are two roots (Fig. 4e).

m1. Nyctalodont tooth, with a ' $V$ ' shaped paralophid. The protoconid is the highest cusp of the trigonid. The paraconid, the metaconid and the entoconid are aligned in occlusal view. The hypoconulid is labially displaced respect the entoconid. The entocristid is concave. The distal base of the trigonid, in the centre of the talonid, has a small spur (Fig. 4f). The lingual cingulum is small. The labial cingulum is wide and connects the base of the paraconid to the hypoconulid. Roots are not preserved.

m2. The tooth is similar to $\mathrm{ml}$ (Fig. 4g), but the spur arising from the trigonid is more developed. Roots are not preserved.

M1. Subquadrangular tooth. The parastyle is broken. The anterior cingulum is wide and connected to the protocone. An independent cingulum is present on the anterior side of the protocone. The labial cingulum of the paraflex and the metaflex are small. The height of the metacone and paracone is similar. The mesostyle is narrow. The metaloph and paraloph are well developed. There is a short postprotocrista. The hypocone is small and connected to the protocone. The talon is small (Fig. 4h). The cingulum of the talon is wide. The distal cingulum is connected to the cingulum of the talon on the lingual side, and not connected to the metastyle on the labial side. Roots are not preserved.

M3. Subtriangular tooth (Fig. 4i). The parastyle is inflated. The anterior cingulum is wide and connected to the protocone, but not to the parastyle. An independent anterior cingulum is present in the protocone. The metacone is reduced. Both the metastyle and the postmetacrista are absent. The paraloph is well developed. The postprotocresta is short and connected to small metaconule. The talon is reduced to a small cingulum. Roots are not preserved.

Remarks. The remains from ACB MB present many of the typical features of Miniopterus, such as a two-rooted p3, nyctalodont lower molars and a well-developed talon in the M1 (Popov, 2004). The specimens of M. fossilis from Petersbuch 18 (Ziegler, 2003) are similar to our material in size and morphology, presenting a lingual cingulum of the trigonid, a complete labial cingulum (although wider in ACB MB molars), and a small spur in the posterior side of the trigonid.

Order EULIPOTYPHLA Waddell, Okada \& Hasegawa, 1999

Suborder Soricomorpha Gregory, 1910

Family Soricidae Fischer, 1814

Tribe Nectogalini Anderson, 1879 


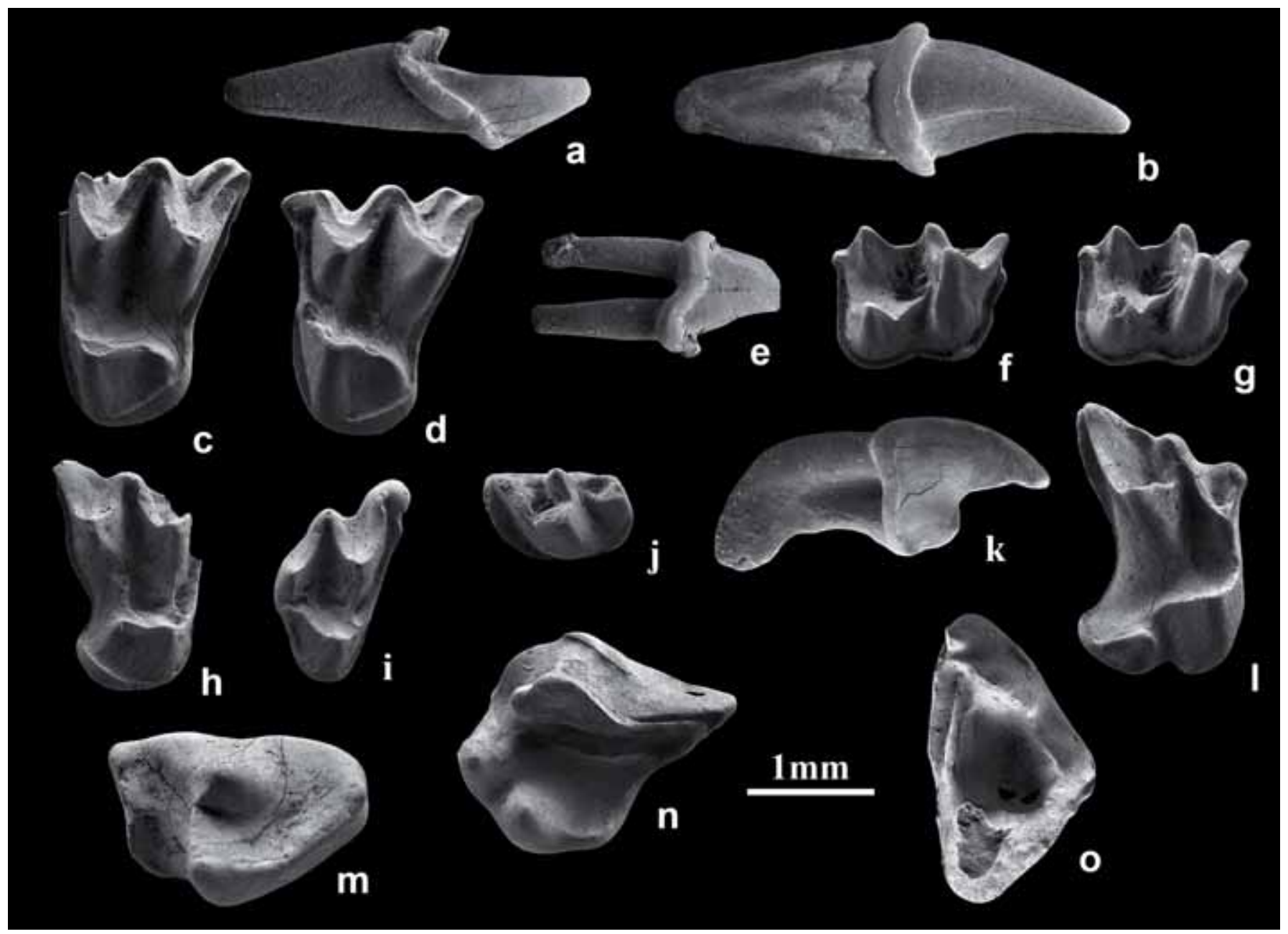

Figure 4. Insectivores and chiropterans from ACBMB. Myotis sp., a) right c, ACBMB-77; b), right C, ACBMB-73; c), left M1, ACBMB-62; d), left M2, ACBMB-63; Miniopterus cf. fossilis, e), left p3, ACBMB-83; f), right m1, ACBMB-52; g), right m2, ACBMB-53; h), left M3, ACBMB-54; i) right M1, ACBMB-55. Asoriculus gibberodon, j), right I1, ACBMB-69; k), left m3, ACBMB-84; l) right M1, ACBMB-68. Parasorex cf. ibericus, m), right p4, ACBMB-80; n), right P3, ACBMB-66; o), right $\mathrm{P} 3, \mathrm{ACBMB}-67$. Scale bar $1 \mathrm{~mm}$.

Genus Asoriculus Kretzoi, 1959

Type species Crocidura gibberodon Petényi, 1854

\section{Asoriculus gibberodon (Petényi, 1854)}

(Figs 4 j-1)

Material. $1 \mathrm{~m} 1 / 2$ (ACBMB-81), $2 \mathrm{~m} 3$ (ACBMB-82, ACBMB-84), 1 I1 (ACBMB-69), 3 M1 (ACBMB-64, ACBMB-65, ACBMB-68).

Measurements. $\mathrm{m} 3: \mathrm{L}=1.17 \times \mathrm{W}=0.64 ; \mathrm{L}=1.21 \times$ $\mathrm{W}=0.67 ; \mathrm{I} 1: \mathrm{L}=1.43 \times \mathrm{LT}=0.65 \times \mathrm{H}=1.13 ; \mathrm{M} 1: \mathrm{PE}=1.13$ $\times \mathrm{AW}=1.61 \times \mathrm{PE}=1.16 \times \mathrm{LL}=1.41 \times \mathrm{AW}=1.65 \times \mathrm{BL}=1.40$ $\times \mathrm{PE}=1.06 \times \mathrm{LL}=1.35 \times \mathrm{AW}=1.67 \times \mathrm{PW}=2.11$.

\section{Description.}

$\mathbf{m 1 / 2}$. The trigonid is the only part preserved. The paralophid and metalophid are ' $\mathrm{V}$ ' shaped. The metaconid and the paraconid have similar height. There is a wide labial cingulum. Roots are not preserved.

m3. The talonid is reduced (Fig. 4j). There are both hypoconid and entoconid. The oblique crest and entocristid are close to contact at the base of the trigonid. The height of the metaconid and paraconid is similar. Paralophid and metalophid are ' $\mathrm{V}$ ' shaped. The depression of the trigonid is open and ' $\mathrm{V}$ ' shaped. The protoconid is the highest cusp. The basal cingulum is complete, and wider on the labial side. Roots are not preserved.

I1. The single principal cusp is curved. A welldeveloped cingulum borders the base of the crown (Fig. $4 \mathrm{k}$ ). Two cusps are present in the ventral side of the cingulum. Roots are not preserved.

M1. The metaloph does not reach the hypocone. There is a well-developed hypoconal flange and a pronounced posterior emargination. The hypocone is high and conical in one specimen and high and elongated in another one 
(Fig. 41). The basal connection between the hypocone and posteroloph is developed. The preprotocrista is in contact with the paracone. The parastyle and mesostyle are rounded. The paracrest is the shortest crest in the ectoloph. The paramesocrest is longer than the postmesocrest. The metastyle is long. The metacone is higher than the paracone. The ectoloph is very asymmetric. Roots are not preserved.

Remarks. Asoriculus gibberodon is characterized by the presence of a small basin in the talonid of the m3 (Reumer, 1984), more reduced than in the genus Neomys (Furió, 2007). Moreover, the lower molars have a complete basal cingulum (Furió, 2007). Reumer (1984) described two different morphologies for the connection between hypocone and posteroloph (A, with isolated and well-developed hypocone; $\mathrm{B}$, with a connected hypocone and posteroloph). The specimens from ACBM MB agree with morphotype $\mathrm{B}$, but one of them has a well-developed hypocone, similar to morphotype A. This morphological variability is typical of A. gibberodon (Reumer, 1984), but our material is smaller than the Plio/Pleistocene populations of this species from Fuente Nueva 3 and Barranco León (Furió, 2007).

Asoriculus gibberodon is common during the Pliocene of Europe (Furió \& Angelone, 2010), but the oldest remains come from the MN12 of Tardosbanya (Mészáros, 1998), and it has been described in the MN13 sites of Polgárdi (Mészáros, 1999), Brisighella (Rofes \& Cuenca-Bescós, 2006) and near the Mio/Pliocene boundary in Maramena (Doukas et al., 1995). Therefore, it is possible to ascribe the specimens from ACB MB to Asoriculus gibberodon.

Family Erinaceidae Fischer, 1814

Subfamily Galericinae Pomel, 1848

Tribe Galericini Pomel, 1848

Genus Parasorex von Meyer, 1865

Type species Parasorex socialis, von Meyer, 1865

Parasorex cf. ibericus (Mein \& Martín-Suárez, 1994) (Figs 4 m-o)

Material. 1 i2 (ACBMB-78), 2 p1 (ACBMB-75, ACBMB-76), 1 p3 (ACBMB-71), 1 p4 (ACBMB-80), 2 I2 (ACBMB-74, ACBMB-79), 1 P1 (ACBMB-72), 1 P2 (ACBMB-70), 1 P3 (ACBMB-66), 1 M3 (ACBMB-67).

Measurements. i2: $\mathrm{L}=0.58 \times \mathrm{W}=0.87 ; \mathrm{p} 1: \mathrm{L}=1.25 \mathrm{x}$ $\mathrm{W}=0.64 ; \mathrm{L}=1.11 \times \mathrm{W}=0.68 ; \mathrm{p} 3: \mathrm{L}=1.53 \times \mathrm{W}=0.90 ; \mathrm{p} 4$ : $\mathrm{L}=2.15 \times \mathrm{W}=1.28 ; \mathrm{I} 2: \mathrm{L}=0.88 \times \mathrm{W}=0.66 ; \mathrm{P} 1: \mathrm{L}=1.42 \times$ $\mathrm{W}=0.81 ; \mathrm{P} 2: \mathrm{L}=1.39 \times \mathrm{W}=0.78 ; \mathrm{P} 3: \mathrm{L}=2.23 \times \mathrm{W}=1.76$; M3: $\mathrm{L}=1.37 \times \mathrm{W}=2.25$.

\section{Description.}

i2. The tooth is thickened, with a principal flat cuspid and an accessory cuspule. There is one large root. p1. The tooth has an elliptical shape. There is a principal cuspid, a well-developed anterior cuspule and a smaller posterior one. There is one large root.

p3. The tooth has a subtriangular shape. Irregular posterior side. There are two roots.

p4. Subrectangular tooth. The paraconid is high, being connected to the paralophid without a clear differentiation between them. The paralophid is straight. The trigonid depression is small. The protoconid is better developed than the metaconid (Fig. $4 \mathrm{~m}$ ). The posterior cingulum is well developed, and it bears a small cuspule near to the lingual side. There are two roots.

I2. The tooth has a tear-like shape. The principal cusp is rounded in cross section, and slightly curved. A small cuspule is present in its posterior side. There is one root.

P1. The tooth has a tear-like shape in occlusal view. There is a cuspule in the posterior part. There are two roots

P2. The tooth has a subtriangular shape, rounded on its anterior side. There is a small cuspule. There are two roots.

P3. Subquadrangular tooth, without enamel on its labial side. The parastyle is absent. The paracone is the largest cusp (Fig. 4n). The protocone is higher than the hypocone, and isolated from this latter cusp. There is a short paramesocrista. The posterior cingulum is wide. Roots are not preserved.

M3. The tooth is triangular. The parastyle is well developed. The anterior cingulum is wide and connected to the parastyle. The paracone is connected to the parastyle. The depression of the trigonid is closed. The protocone is the largest cusp. The posterior cingulum is absent (Fig. $40)$. Roots are not preserved.

Remarks. The presence of a triangular M3 is characteristic of the subfamily Galericinae (Lopatin, 2006), and having a metaconid in $\mathrm{p} 3$ is a typical trait of the genus Parasorex (Hoek Ostende, 2001). The absence or reduced posterior cingulum in the M3 is a typical feature of P. ibericus (Mein \& Martín-Suárez, 1994). Therefore, we ascribe this material to Parasorex cf. ibericus.

\section{BIOSTRATIGRAPHY}

The faunal list of ACB MB is shown in table 4. The cooccurrence of Occitanomys alcalai, Paraethomys meini and Stephanomys dubari is typical of the late Turolian/earliest Ruscinian (García-Alix et al., 2008a, 2008d).

Muscardinus vireti is present in the late Turolian localities of Lissieu and Junqueras 2B, being replaced by its descendant, $M$. meridionalis near the Mio/Pliocene boundary (García-Alix et al., 2008c). The specimen from ACB MB belongs to the lineage M. meridionalis-M. vireti, but its ascription is uncertain because of the scarcity of the material. 
Table 4. Faunal list of the locality ACB MB.

\begin{tabular}{|c|c|c|c|c|c|c|}
\hline Muridae & Cricetidae & Gliridae & Sciuridae & Soricidae & Erinaceidae & Vespertilionidae \\
\hline $\begin{array}{l}\text { Occitanomys } \\
\text { alcalai }\end{array}$ & Apocricetus sp. & Eliomys truci & Heteroxerus sp. & $\begin{array}{l}\text { Asoriculus } \\
\text { gibberodon }\end{array}$ & $\begin{array}{l}\text { Parasorex cf. } \\
\text { ibericus }\end{array}$ & Myotis sp. \\
\hline $\begin{array}{l}\text { Paraethomys } \\
\text { meini }\end{array}$ & $\begin{array}{l}\text { Ruscinomys cf. } \\
\text { schaubi }\end{array}$ & Eliomys sp. & & & & $\begin{array}{l}\text { Miniopterus } \\
\text { fossilis }\end{array}$ \\
\hline $\begin{array}{l}\text { Stephanomys } \\
\text { dubari }\end{array}$ & & $\begin{array}{l}\text { Muscardinus cf. } \\
\text { vireti }\end{array}$ & & & & \\
\hline
\end{tabular}

Nevertheless, the presence of some remains of Paraethomys close in size to the Pliocene Paraethomys aff. abaigari and two species of Eliomys, which hitherto had only been described in Pliocene localities (Adrover, 1986; Castillo, 1990; Mein et al., 1990; García-Alix et al., $2008 \mathrm{~b}$ ), suggests that the age of ACB MB may be indeed early Ruscinian. This age makes ACB MB probably the oldest locality with two different Eliomys species, since the only other locality from the MN14 with two Eliomys is La Gloria 4 (Mein et al., 1990), and the other known localities are assigned to MN15/MN16 (Mein et al., 1990; García-Alix et al., 2008b). This supports the hypothesis of a late Miocene cladogenetic speciation process of Eliomys, giving rise to the lines of E. truci and E. yevesi-E. intermedius near the Mio/Pliocene boundary (García-Alix et al., 2008b; Mansino et al., 2015b). Furthermore, this dating makes of Miniopterus fossilis from ACB MB the youngest record of this species, which until now was the MN13 site of Salobreña (Aguilar et al., 1984).

An early Pliocene age makes ACB MB one of the oldest localities from the Almenara-Casablanca complex, being only younger than nearby late Turolian site of ACB M (Agustí et al., 2011) (Figs 1-2). In this locality, Agustí et al. (2011) described an assemblage typical of the MN13, clearly older than ACB MB by the presence of Stephanomys ramblensis, Occitanomys adroveri, Apodemus gudrunae and Apocricetus alberti. Furthermore, ACB M has yielded a number of taxa with African and Asian affinities, such as the gerbils Debruijnimys almenarensis and Pseudomeriones abbreviatus and the myocricetodontines Myocricetodon jaegeri and Calomyscus sp. (Agustí et al., 2011), which are absent in ACB MB.

\section{PALAEOECOLOGY}

The analysis of the proportions of the micromammal species has been extensively used in palaeoclimatic reconstructions. The minimum sample size has been placed in 100 specimens by some authors (Daams et al., 1999; García-Alix et al., 2008e), while others considered samples over 50 diagnostic elements to be acceptable (CasanovasVilar \& Agustí, 2007). Since ACB MB has yielded 93 identifiable remains (Table 5), we consider proper to perform a palaeoecological analysis of this locality.

In this work, we have followed the ecological affinities proposed by García-Alix et al. (2008e) and Freudenthal et al. (2014) in order to attempt a palaeoclimatic reconstruction of ACB MB. These affinities are summarized in Table 5.

Eurytopic taxa are the most numerous in the three environmental categories considered (temperature, humidity and habitat, Table 5). However, the relative abundance of warm indicators $(42.36 \%$, Table 5$)$ and the higher proportion of wet indicators respect dry indicators (23.54 versus $18.82 \%$, Table 5) would point to a warm and relatively humid environment, and the presence of forest taxa suggest some degree of vegetation cover (Table 5). This scenario is more humid than the conditions inferred for ACB M by Agustí et al. (2011), which are regarded as dry and sub-desertic.

The analysis of fossil micromammal communities shows a moderate increase in humidity from the latest Messinian towards the Early Pliocene in the Granada Basin (García-Alix et al., 2008e; García-Alix, 2015), and a marked reduction of dry indicators from the Miocene/ Pliocene boundary to the early Pliocene in the Alcoy Basin (Mansino et al., in press). Under this frame, the apparent lack of gerbils in ACB MB, which are considered typical of desertic environments, may be a consequence of a shift towards wetter conditions in the early Pliocene. However, more intense sampling must be performed before discarding the presence of these taxa in $\mathrm{ACB} \mathrm{MB}$, and for the moment these considerations are just speculative.

\section{CONCLUSIONS}

The new site of ACB MB has yielded remains of Occitanomys alcalai, Paraethomys meini, Stephanomys dubari, Eliomys truci, Eliomys sp., Muscardinus cf. vireti, Apocricetus sp., Ruscinomys cf. schaubi, Heteroxerus sp., Myotis sp., Miniopterus fossilis, Asoriculus gibberodon and Parasorex cf. ibericus. This faunal assemblage suggests an earliest Ruscinian age, close to the Mio/Pliocene boundary, for this locality. 
Table 5. Palaeoecological affinities of the taxa from ACB MB. The relative abundance (RA) of each taxon is calculated following Martín-Suárez (1988), dividing the number of specimens (N) by the number of diagnostic elements (DE) of each group.

\begin{tabular}{|c|c|c|c|c|c|c|c|}
\hline & $\mathbf{N}$ & DE & N/DE & RA (\%) & Temperature & Humidity & Habitat \\
\hline $\begin{array}{l}\text { Occitanomys } \\
\text { alcalai }\end{array}$ & 13 & 12 & 1.08 & 17.79 & Warm & Humid & Eurytopic \\
\hline $\begin{array}{l}\text { Paraethomys } \\
\text { meini }\end{array}$ & 12 & 12 & 1.00 & 16.42 & Warm & Dry & Eurytopic \\
\hline $\begin{array}{l}\text { Stephanomys } \\
\text { dubari }\end{array}$ & 30 & 12 & 2.50 & 41.06 & Eurytopic & Eurytopic & Eurytopic \\
\hline Eliomys & 5 & 16 & 0.31 & 5.13 & Eurytopic & Eurytopic & Eurytopic \\
\hline Muscardinus & 1 & 16 & 0.06 & 1.03 & Eurytopic & Eurytopic & Forest \\
\hline Apocricetus & 1 & 12 & 0.08 & 1.37 & Warm & Eurytopic & Open \\
\hline Ruscinomys & 1 & 12 & 0.08 & 1.37 & Cold & Dry & Open \\
\hline Heteroxerus & 1 & 16 & 0.06 & 1.03 & Warm & Dry & Open \\
\hline Myotis & 6 & 38 & 0.16 & 2.59 & Unknown & Unknown & Unknown \\
\hline $\begin{array}{l}\text { Miniopterus } \\
\text { fossilis }\end{array}$ & 5 & 38 & 0.13 & 2.16 & Unknown & Unknown & Unknown \\
\hline $\begin{array}{l}\text { Asoriculus } \\
\text { gibberodon }\end{array}$ & 7 & 20 & 0.35 & 5.75 & Warm & Humid & Forest \\
\hline $\begin{array}{l}\text { Parasorex } \\
\text { ibericus }\end{array}$ & 11 & 42 & 0.26 & 4.30 & Eurytopic & Eurytopic & Eurytopic \\
\hline \multirow[t]{2}{*}{ Total } & 93 & & 6.09 & & & & \\
\hline & & & & & $\begin{array}{l}\text { Warm } 42.36 \% \\
\text { Cold } 1.37 \% \\
\text { Eurytopic } 51.52 \\
\% \\
\text { Unknown } \\
4.75 \%\end{array}$ & $\begin{array}{l}\text { Humid } 18.82 \% \\
\text { Dry } 23.54 \% \\
\text { Eurytopic } 52.89 \\
\% \\
\text { Unknown } \\
4.75 \%\end{array}$ & $\begin{array}{l}\text { Open } 3.76 \% \\
\text { Forest } 6.77 \% \\
\text { Eurytopic } 84.71 \\
\% \\
\text { Unknown } \\
4.75 \%\end{array}$ \\
\hline
\end{tabular}

The palaecological analysis of the micromammal assemblage from ACB MB points to a warm and relatively humid environment, with some vegetation cover. These results contrast with those from the nearby locality of ACB M, in which the presence of gerbils suggests a subdesertic environment. Since a trend towards more humid conditions from the latest Turolian to the earliest Ruscinian has been recorded in some Iberian basins such as the Granada and Alcoy basins, we hypothesize that a shift in the environmental conditions may affect the distribution of gerbils in the Iberian Peninsula.

In addition, the presence of two Eliomys species in ACB MB, a small form identified as E. truci, and a larger form belonging to the line E. yevesi-E. intermedius, represents the oldest record of two species of this genus in the same locality, supporting the hypothesis of a cladogenetic process of speciation during Late Miocene.

Finally, the remains of Miniopterus fossilis constitute the youngest record of this species, which until now was the MN13 site of Salobreña.

\section{ACKNOWLEDGEMENTS}

We would like to thank the Sociedad Española de Paleontología (SEP) for the concession of a research grant to SM, which has supported the fieldworks in ACB MB. The prospection works (number 2006/0212-Cs) were carried out in the frame of contract CNME06/PL55S/619 of the Consellería de Cultura, Educación y Ciencia de la Generalitat Valenciana, within the project GV06/304. F.J.R-S and J.A. thank the "Proyecto Prometeo" of the "Secretaría de Educación Superior, Ciencia Tecnología e Innovación", Republic of Ecuador. This study was also supported by the Spanish Ministerio de Economía y Competitividad (CGL2011-25754 and CGL2011-28681). In addition, we would like to thank all the students from the Universitat de València who have participated in the fieldwork and washing of sediments. Finally, we would like to thank the editor Julio Aguirre and the reviewers Drs. Adriana Oliver and Carolina Castillo for their useful comments and suggestions. 


\section{REFERENCES}

Adrover, R. 1969. Los micromamíferos del Plioceno inferior de los lignitos de Alcoy. I. Ruscinomys. Boletín de la Real Sociedad Española de Historia Natural (Sección Geológica), 67, 245-272.

Adrover, R. 1986. Nuevas faunas de roedores en el MioPlioceno continental de la región de Teruel (España). Interés bioestratigráfico y paleoecológico. 423 pp. Ph.D. Thesis, Publicaciones del Instituto de Estudios Turolenses, Teruel.

Adrover, R., Mein, P. \& Moissenet, E. 1988. Contribución al conocimiento de la fauna de roedores del Plioceno de la región de Teruel. Teruel, 79, 89-151.

Adrover, R., Mein, P. \& Moissenet, E. 1993. Roedores de la transición Mio-Plioceno de la región de Teruel. Paleontologia i Evolució, 26-27, 47-84.

Aguilar, J.P., Grandy, L.D. \& Thaler, L. 1984. Les rongeurs de Salobreña (Sud de I'Espagne) et le probléme de la migration messinienne. Paléobiologie Continentale, 14, 3-17.

Aguilar, J.P., Michaux, J. \& Lazzari, V. 2007. Lo Fournas 16-M (Miocène supérieur) et Lo Fournas 16-P (Pliocène moyen), deux nouvelles localités karstiques à Baixas, Sud de la France. Partie II - Nouvelles espèces de rongeurs, listes fauniques et remarque sur l'utilisation biochronologique des faunes karstiques. Géologie de la France, 1, 63-81.

Agustí, J., Santos-Cubedo, A., Furió, M., De Marfá, R., Blain, H.A., Oms, O. \& Sevilla, P. 2011. The late Neogene-early Quaternary small vertebrate succession from the Almenara-Casablanca karst complex (Castellón, Eastern Spain): Chronologic and paleoclimatic context. Quaternary International, 243, 183-191; doi: 10.1016/j. quaint.2010.11.016.

Anderson, J. 1879. Anatomical and Zoological Researches in Western Yunnan. Quaritch, London, p. 984.

Baudelot, S. 1972. Etude des chiroptères, insectivores et rongeurs du Miocène de Sansan. 364 pp. Ph.D. Thesis Universite Paul Sabatier, Toulouse.

Blumenbach, J.F. 1779. Handbuch der Naturgeschichte. p. 448.

Bonaparte. 1837. Iconografia della Fauna Italica per le Quattro Classi degli Animali Vertebrati, 3 (19-21), 94-103.

Borkhausen, M.B. 1797. Botanisches Wörterbuch oder Versuch einer Erklärung der vornehmsten Begriffe und Kunstwörter in der Botanik. Gießen, 2 Bände.

Bowdich, T.E. 1821. An Analysis of the Natural Classification of Mammalia for the Use of Students and Travellers. p. 115.

Brandt, J.F. 1855. Beiträge zur nähern Kenntniss der Säugetheire Tussland's. Memoir Academic. Imperial Science St. Petersbourg, series, 6, 1-365.

Casanovas-Vilar, I. \& Agustí, J. 2007. Ecogeographical stability and climate forcing in the Late Miocene (Vallesian) rodent record of Spain. Palaeogeography, Palaeoclimatology, Palaeoecology, 248, 169-189; doi: 10.1016/j.palaeo.2006.12.002.
Castillo, C. 1990. Paleocomunidades de micromamíferos de los yacimientos kársticos del Neógeno superior de Andalucía Oriental. 225 pp. Ph.D. Thesis, Universidad de Granada (unpublished).

Colombero, S., Pavia, G. \& Carnevale, G. 2014. Messinian rodents from Moncucco Torinese, NW Italy: palaeobiodiversity and biochronology. Geodiversitas, 36 , 421-475; doi: 10.5252/g2014n3a4.

Cordy, J.M. 1976. Essai sur la microévolution du genre Stephanomys (Rodentia, Muridae). 351 pp. Ph.D. Thesis, Université de Liège.

Cuenca-Bescós, G. 1988. Revisión de los Sciuridos del Aragoniense y del Rambliense en la fosa de CalatayudMontalbán. Scripta Geologica, 87, 1-116.

Daams, R. 1981. The dental pattern of the Dormice Dryomys, Myomimus, Microdyromys and Peridyromys. Utrecht Micropaleontological Bulletins, Special Publication, 3, $1-115$.

Daams, R., Meulen, A.J. van der, Peláez-Campomanes, P. \& Álvarez-Sierra, M.A. 1999. Trends in rodent assemblages from the Aragonian (early-middle Miocene) of the Calatayud-Daroca Basin, Aragón, Spain. In: Hominoid Evolution and Climatic Change in Europe. The Evolution of Terrestrial Ecosystems in Europe (eds Agustí, J., Rook, L. \& Andrews, P.). Cambridge University Press, 127-139.

de Bruijn, H., 1967. Gliridae, Sciuridae y Eomyidae (Rodentia, Mammalia) miocenos de Calatayud (provincia de Zaragoza, España) y su relación con la bioestratigrafía del área. Boletín del Instituto Geológico y Minero de España, 78, 187-373.

de Bruijn, H., Mein, P., Montenat, C. \& Weerd, A. van de. 1975. Corrélations entre les gisements de rongeurs et les formations marines du Miocéne terminal d'Espagne méridional I (Provinces d'Alicante et de Murcia). Proceedings Koninklijke Akademie van Wetenschappen, 78, 314-338.

Depéret, C. 1890. Les animaux pliocènes du Roussillon. Mémoires de la Société géologique de France, Paleontologie, 3, 1-194.

Dobson, G.E. 1875. On the genus Scotophilus, with description of a new genus and species allied thereto. Proceedings of the Zoological Society of London, 368-373.

Doukas C.S., Hoek Ostende, L.W. van den, Theocharopoulos C.D. \& Reumer J.W.F. 1995. The vertebrate locality Maramena (Macedonia, Greece) at the Turolian-Ruscinian boundary (Neogene). Insectivora (Erinaceidae, Talpidae, Soricidae, Mammalia). Münchner Geowissenschaftliche Abhandlungen Reihe A, 28, 43-64.

Eversmann, E. 1845. Bulletin de la Société impériale des naturalistes de Moscou, 18, 505.

Fejfar, O. \& Storch, G. 1990. Eine pliozäne (ober-ruscinische) Kleinsäugerfauna aus Gundersheim, Rheinhessen. I. Nagetiere: Mammalia, Rodentia. Senckenbergiana Lethaea, 71, 139-184.

Fischer, G. 1813-1814. Zoognosia tabulis synopticis illustrata. Nicolai Sergeidis Vsevolozsky, Moscow, 3, 3-1814.

Fischer, G. 1817. Adversaria zoological. Mémoires de la Société impériale des Naturalistes de Moscou, 5, 357-472. 
Forsyth Major, C.J. 1893. On some Miocene Squirrels, with remarks on the Dentition and Classification of the Sciurinae. Proceedings of the Zoological Society of London, 179-215.

Freudenthal, M. 2004. Gliridae (Rodentia, Mammalia) from the Eocene and Oligocene of the Sierra Palomera (Teruel, Spain). Treballs del Museu de Geologia de Barcelona, 12, 97-173.

Freudenthal, M., Lacomba, J.I. \& Martín-Suárez, E., 1991. The Cricetidae (Mammalia, Rodentia) from the Late Miocene of Crevillente (prov. Alicante, Spain). Scripta Geologica, 96, 9-46.

Freudenthal, M., Mein, P. \& Martín-Suárez, E. 1998. Revision of Late Miocene and Pliocene Cricetinae (Rodentia, Mammalia) from Spain and France. Treballs del Museu de Geologia de Barcelona, 7, 11-93.

Freudenthal, M., García-Alix, A., Ríos, M., Ruiz-Sánchez, F.J., Martín-Suárez, E. \& Delgado Huertas, A. 2014. Review of paleo-humidity parameters in fossil rodents (Mammalia): Isotopic vs. tooth morphology approach. Palaeogeography, Palaeoclimatology, Palaeoecology, 395, 122-130; doi: 10.1016/j.palaeo.2013.12.023.

Friant, M. 1953. Une faune du Quaternaire ancien en France méditerranéenne (Sète, Hérault). Annales de la Société Géologique du Nord, 73, 161-170.

Furió, M. 2007. Los insectívoros (Soricomorpha, Erinaceomorpha, Mammalia) del Neógeno Superior del Levante Ibérico. 299 pp. Ph.D. Thesis, Universitat Autònoma de Barcelona (unpublished).

Furió, M. \& Angelone, C. 2010. Insectivores (Erinaceidae, Soricidae, Talpidae; Mammalia) from the Pliocene of Capo Mannu D1 (Mandriola, central-western Sardinia, Italy). Neues Jahrbuch für Geologie und Paläontologie, Abhandlungen, 258, 229-242; doi: 10.1127/00777749/2010/0100.

Furió, M., Santos-Cubedo, A., Blain, H.-A., Blaya, E., Casanovas, I., Madurell, J. \& Alba, D.M. 2005. Síntesis sobre las faunas fósiles del complejo cárstico AlmenaraCasablanca (Castellón). In: Miscelánea Paleontológica (eds Meléndez, G., Martínez-Pérez, C., Ros, S., Botella, H. \& Plasencia, P.). Publicaciones del Seminario de Paleontología de Zaragoza, Zaragoza-Macastre, 273-286.

Galán, J., Cuenca-Bescós, G., López-García, J.M., Sauqué, V. \& Núñez-Lahuerta, C. In press. Fossil bats from the Late Pleistocene site of the Aguilón P7 Cave (Zaragoza, Spain). Comptes Rendus Palevol, 15, 501-514; doi: 10.1016/j. crpv.2014.12.003.

García-Alix, A. 2006. Bioestratigrafía de los depósitos continentales de la transición Mio-Plioceno de la cuenca de Granada. 429 pp. Ph.D. Thesis, Universidad de Granada (unpublished).

García-Alix, A. 2015. A multiproxy approach for the reconstruction of ancient continental environments. The case of the Mio-Pliocene deposits of the Granada Basin (southern Iberian Peninsula). Global Planetary Change, 131, 1-10; doi: 10.1016/j.gloplacha.2015.04.005.

García-Alix, A., Minwer-Barakat, R., Martín-Suárez, E. \& Freudenthal, M. 2008a. Muridae (Rodentia,
Mammalia) from the Mio-Pliocene boundary in the Granada Basin (southern Spain). Biostratigraphic and phylogenetic implications. Neues Jahrbuch für Geologie und Paläontologie, Abhandlungen, 248, 183-215; doi: 10.1127/0077-7749/2008/0248-0183.

García-Alix, A., Minwer-Barakat, R., Martín-Suárez, E. \& Freudenthal, M. 2008b. Cricetidae and Gliridae (Rodentia, Mammalia) from the Miocene and Pliocene of southern Spain. Scripta Geologica, 136, 1-37.

García-Alix, A., Minwer-Barakat, R., Martín, J.M., MartínSuárez, E. \& Freudenthal, M. 2008c. Muscardinus meridionalis sp. nov., a new species of Gliridae (Rodentia, Mammalia) and its implications for the phylogeny of Muscardinus. Journal of Vertebrate Paleontology, 28, 568-573; doi: 10.1671/0272-4634(2008)28[568:MMSN $\mathrm{AN}] 2.0 . \mathrm{CO} ; 2$.

García-Alix, A., Minwer-Barakat, R., Martín, J.M., MartínSuárez, E. \& Freudenthal, M. 2008d. Biostratigraphy and sedimentary evolution of Late Miocene and Pliocene continental deposits of the Granada Basin (southern Spain). Lethaia, 41, 431-446; doi: 10.1111/j.15023931.2008.00097.x.

García-Alix, A., Minwer-Barakat, R., Martín-Suárez, E., Freudenthal, M. \& Martín, J.M. 2008e. Late MioceneEarly Pliocene climatic evolution of the Granada Basin (southern Spain) deduced from the paleoecology of the micromammal associations. Palaeogeography, Palaeoclimatology, Palaeoecology, 265, 214-225; doi: 10.1016/j.palaeo.2008.04.005.

Geoffroy, E. 1806. Annales du Museum National d'Histoire naturelle de Paris, 8: 198.

Gil, E. \& Sesé, C. 1985. Micromamíferos (Insectivora, Rodentia y Lagomorpha) del nuevo yacimiento Villafranquiense de Casablanca B (Almenara, Prov. de Castellón). Estudios Geológicos, 41, 945-501.

Gray, J.E. 1821. On the natural arrangement of Vertebrose Animals. London Medical Repository, 15, 296-310.

Gregory, W.K. 1910. The orders of mammals. Bulletin of the American Museum of Natural History, 27, 1-524.

Gunnell, G.F., Eiting, T.P. \& Geraads, D. 2011. New late Pliocene bats (Chiroptera) from Ahl al Oughlam, Morocco. Neues Jahrbuch für Geologie und Paläontologie, 260, 5571; doi: 10.1127/0077-7749/2011/0128.

Gusi, F. 2003. Introducción al yacimiento. In: Roedores, Monos, Caballos y Ciervos (ed. Gusi, F.). Colección de Prehistoria y Arqueología castellonenses. Servei d'Investigacions Arqueològiques i Prehistòriques, Diputació de Castelló, 17-29.

Hartenberger, J.L. 1967. Les rongeurs du Vallésien (Miocène supérieur) de Can Llobateres (Sabadell, Espagne): Gliridae et Eomyidae. Bulletin de la Société Géologique de France, 7, 596-604.

Heller, F. 1936. Eine oberpliozane Wirbeltierfauna aus Rheinhessen. Neues Jahrbuch für Mineralogie, Geologie und Paläontologie, 76, 99-160.

Hoek Ostende, L.W. van den. 2001. A revised generic classification of the Galericini (Insectivora, Mammalia) with some remarks on their palaeobiogeography and 
phylogeny. Geobios, 34, 681-695; doi: 10.1016/S00166995(01)80029-2.

Hugueney, M. \& Mein, P. 1965. Lagomorphes et rongeurs du Neogene de Lissieu. Travaux du Laboratoire de Geologie, Faculte des Sciences, Lyon, Nouvelle Serie, 12, 109-123.

Illiger, C. 1811. Prodromus Systematis Mammaliurn et Avium Additis Terminis Zoographicis Utriusque Classis, p. 301.

Kaup, J. 1829. Skizzierte Entwicklungsgeschichte und Natiirliches System der Europaischen Thierwelt, p. 203.

Kowalski, K. 1956. Insectivores, bats and rodents from the Early Pleistocene bone breccia of Podlesice near Kroczyce (Poland). Acta Palaeontologica Polonica, 1, 331-394.

Kretzoi, M. 1959. Insectivoren, nagetiere und lagomorphen der jüngstpliozänen fauna von Csarnóta im Villányer Gebirge (Südungarn). Vertebrata hungarica, 1, 237-246.

Kuhl, H. 1817. Die deutschen Fledermäuse. Hanau (privately published), $67 \mathrm{pp}$.

Linnaeus, C. 1758. Systema Naturce per Regna Tria Naturce, Secundum Classes, Ordines, Genera, Species, cum Characteribus, Differentiis, Synonymis, Locis. Tomus I. Editio decima, Reformata. Holmice. (Salvius), p. 824.

Linnaeus, C. 1766. Systema Naturce per Regna Tria Naturce, Secundum Classes, Ordines, Genera, Species, cum Characteribus, Differentiis, Synonymis, Locis. Tomus I. Editio duodecima, Reformata. Holmiae. (Laurentii Salvii), p. 532.

Lopatin, A.V. 2006. Early Paleogene insectivore mammals of Asia and establishment of the major groups of Insectivora. Paleontological Journal, 40, 205-405; doi: 10.1134/ S0031030106090012.

Mansino, S., Fierro, I., Ruiz-Sánchez, F.J. \& Montoya, P. 2013. The fossil rodent faunas of the localities Alcoy $2 \mathrm{C}$ and 2D (Alcoy Basin, Spain). Implications for dating the classical locality of 2 Alcoy-Mina. Journal of Iberian Geology, 39, 261-284; doi: 10.5209/rev_JIGE.2013.v39. n2.42501.

Mansino, S., Fierro, I., Montoya, P. \& Ruiz-Sánchez, F.J. 2015a. Micromammal faunas from the Mio-Pliocene boundary in the Alcoy Basin (SE Spain): biostratigraphical and palaeoecological inferences. Bulletin of Geosciences, 90, 555-576; doi: 10.3140/bull.geosci.1541.

Mansino, S., García-Alix, A., Ruiz-Sánchez, F.J. \& Montoya, P. 2015b. A new Eliomys from the Late Miocene of Spain and its implications for the phylogeny of the genus. Acta Palaeontologica Polonica, 60, 577-588; doi: 10.4202/ app.00014.2013.

Mansino, S., Ruiz-Sánchez, F.J., Fierro, I. \& Montoya, P. In press. Mio-Pliocene rodent assemblages from Alcoi Forn (Alcoy Basin, Eastern Spain). Biostratigraphical and palaeoclimatical inferences. Historical Biology; doi: 10.1080/08912963.2015.1102238.

Mansino, S., Ruiz-Sánchez, F.J., Freudenthal, M. \& Montoya, P. 2014. A new approach to the Late MioceneEarly Pliocene forms of the genus Apocricetus. Apocricetus alberti (Rodentia, Mammalia) from Venta del Moro (Cabriel Basin, Spain). Proceedings of the Geologists' Association, 125, 392-405; doi: 10.1016/j. pgeola.2014.07.002.
Martín-Suárez, E. 1988. Sucesiones de micromamíferos en la depresión Guadix-Baza. 241 pp. Ph.D. Thesis, Universidad de Granada (unpublished).

Martín-Suárez, E. \& Freudenthal, M. 1993. Muridae (Rodentia) from the Lower Turolian of Crevillente (Alicante, Spain). Scripta Geologica, 103, 65-118.

Mayr, H. 1979. Gebissmorphologische Untersuchungen an miozänen Gliriden (Mammalia, Rodentia) Süddeutschlands. 380 pp. Ph.D. Thesis, Universität Munchen, (unpublished).

Mein, P. \& Freudenthal, M. 1971. Une nouvelle classification des Cricetidae (Mammalia, Rodentia) du Tertiaire de 1'Europe. Scripta Geologica, 2, 1-37.

Mein, P. \& Martín-Suárez, E. 1994. Galerix iberica sp. nov. (Erinaceidae, Insectivora, Mammalia) from the late Miocene and Early Pliocene of the Iberian Peninsula. Geobios, 26, 723-730; doi: 10.1016/S00166995(93)80055-V.

Mein, P. \& Michaux, J.J. 1970. Un nouveau stade dans l'évolution des rongeurs pliocènes de l'Europe sudoccidentale. Comptes Rendus des Séances de l'Académie des Sciences de Paris, D270, 2780-2783.

Mein, P., Moissenet, E., \& Adrover, R. 1990. Biostratigraphie du Néogène Supérieur du bassin de Teruel. Paleontologia i Evolució, 23, 121-139.

Mészáros, L.G. 1998. Late Miocene Soricidae (Mammalia) from Tardosbánya (Western Hungary). Hantkeniana, 2, 103-125.

Mészáros, L.G. 1999. An exceptionally rich Soricidae (Mammalia) fauna from the upper Miocene localities of Polgárdi (Hungary). Annales Universitatis Scientiarum Budapestinensis, Sectio Geologica, 32, 5-34.

Meyer, H. von. 1865. Ueber die fossilen Reste von Wirbelthieren, welche die Herren von Schlagintweit von ihren Reisen in Indien und Hoch-Asien mitgebracht haben. Palaeontographica, (1846-1933), 1-40.

Michaux, J. 1969. Muridae (Rodentia) du Pliocene superieur d'Espagne et du Midi de la France. Palaeovertebrata, $3,1-25$

Minwer-Barakat, R., García-Alix, A., Agustí, J., MartínSuárez, E. \& Freudenthal, M. 2009a. The micromammal fauna from Negratín-1 (Guadix basin, Southern Spain): new evidence of African-Iberian mammal exchanges during the late Miocene. Journal of Paleontology, 83, 854-879; doi: 10.1666/09-009.1.

Minwer-Barakat, R., García-Alix, A., Martín-Suárez, E. \& Freudenthal, M. 2009b. Late Turolian micromammals from Rambla de Chimeneas-3: considerations on the oldest continental faunas from the Guadix Basin (Southern Spain). Neues Jahrbuch für Geologie und Paläontologie, 251, 95-108; doi: 10.1127/0077-7749/2009/0251-0095.

Minwer-Barakat, R., García-Alix, A., Martín-Suárez, E. \& Freudenthal, M. 2011. Validation of the species Stephanomys progressus, a murid (Rodentia) from the Early Pleistocene of Spain. Journal of Paleontology, 85, 392-394; doi: 10.1666/10-131.1.

Montenat, C. \& de Bruijn, H. 1976. The Ruscinian rodent faunule from La Juliana (Murcia); its implication for the correlation of continental and marine biozones. 
Proceedings Koninklijke Nederlandse Akademie van Wetenschappen (B), 79, 245-255.

Muirhead, L. 1819. Mazology. In: The Edinburgh Encyclopedia (ed. Brewster, D.). William Blackwood, Edinburgh, 13, 393-486.

Petényi, S.J. 1854. Bihar megyének a Sebes-es Fekete Körös közötti hegyláncain tett természettudományi utazás rövid vázlata. Magyar Academiai Értesítő, 224-233.

Petter, F. 1968. Un muridé Quaternaire nouveau d'Algérie, Paraethomys filfilae. Ses rapports avec les Muridés actuels. Mammalia, 32, 54-59.

Pomel, A. 1848. Etudes sur les carnassiers insectivores (Extrait). Seconde partie - Classification des insectivores. Archives des Sciences Physiques et Naturelles, Genève, 9, 244-251.

Popov, V.V. 2004. Pliocene small mammals (Mammalia, Lipotyphla, Chiroptera, Lagomorpha, Rodentia) from Muselievo (North Bulgaria). Geodiversitas, 26, 403-491.

Reumer, J.W.F. 1984. Ruscinian and Early Pleistocene Soricidae (Insectivora, Mammalia) from Tegelen (The Netherlands) and Hungary. Scripta Geologica, 73, 1-173.

Rofes, J. \& Cuenca-Bescós, G. 2006. First evidence of the Soricidae (Mammalia) Asoriculus gibberodon (Petényi, $1864)$ in the Pleistocene of North Iberia. Rivista Italiana di Paleontologia e Stratigrafia, 112, 301-315; doi: 10.13130/2039-4942/6343.

Rosina, V.V. \& Kruskop, S.V. 2011. The validity of the species Myotis podlesicensis Kowalski, 1956 (Vespertilionidae, Chiroptera) from the Early Pliocene of Poland. Neues Jahrbuch für Geologie und Paläontologie, Abhandlungen, 260, 1-10; doi: 10.1127/0077-7749/2011/0122.

Rosina, V.V. \& Semenov, Y.A. 2012. New taxa of vespertilionid bats (Chiroptera, Mammalia) from the Late Miocene of Ukraine. Neues Jahrbuch für Geologie und Paläontologie, 264, 191-203; doi: 10.1127/0077-7749/2012/0236.

Ruiz-Sánchez, F.J. \& Montoya, P. 2009. Informe sobre la prospección paleontológica en la cantera de la Muntanyeta dels Estanys d'Almenara (Conselleria de Cultura i Esports). Generalitat Valenciana. Unpublished, 1-77.

Ruiz-Sánchez, F.J., Freudenthal, M., Mansino, S., Crespo, V.D. \& Montoya, P. 2014. Apocricetus barrierei (Rodentia, Mammalia) from La Bullana 2B and La Bullana 3 (Cabriel Basin, Valencia, Spain). Revision of the Late Miocene-Early Pliocene forms of the genus Apocricetus. Paläontologische Zeitschrift, 88, 85-98; doi: 10.1007/ s12542-013-0178-0.
Schaub, S. 1938. Tertiare und Quartare Murinae. Abhandlungen der Schweizerischen Palaontologischen Gesellschaft, 61, $1-38$.

Sevilla, P. 1988. Estudio paleontológico de los quirópteros del Cuaternario español. Paleontologia i Evolució, 22, 113-233.

Sevilla, P. \& Chaline, J. 2004. The fossil Middle Pleistocene bats from the Cave of Aldène (Hérault, France). In: Miscelánea en Homenaje a Emiliano Aguirre. Paleontología (eds Baquedano, E. \& Rubio, S.). Paleontología, 4, 593-602.

Stehlin, H.G. \& Schaub, S. 1951. Die Trigonodontie der simplicidentaten Nager. Schweizerische Paläontologische Abhandlungen, 67, 1-385.

Thomas, O. 1897. On the genera of rodents: an attempt to bring up to date the current arrangement of the order. Proceedings of the Zoological Society of London, 50-76.

Tomes, R.F. 1857. Descriptions of four undescribed species of bats. Proceedings of the Zoological Society of London, $25,50-54$.

Villalta, J.F. de \& Crusafont, M. 1956. Un nouveau Ruscinomys du Pontien Espagnol et sa position systématique. Comptes Rendus Société Géologique de France, 7, 91-93.

Waddell, P.J., Okada, N. \& Hasegawa, M. 1999. Towards resolving the interordinal relationships of placental mammals. Systematic Biology, 48, 1-5.

Wagner, J.A. 1840. Beschreibung einiger neuer Nager. Abhandlungen mathematisch-physische Classe, Königliche Bayerische Akademie der Wissenschafen München, 3, 173-218.

Weerd, A. van de. 1976. Rodent faunas of the Mio-Pliocene sediments of the Teruel-Alfambra Region, Spain. Utrecht Micropaleontological Bulletins Special Publication, 2, 1-217.

Zapfe, H. 1950. The fauna of the Miocene fissure filling from Neudorf and der March (ČSR). Chiroptera. Österreichische Akademie der Wissenschaften, MathematischNaturwissenschaftlichen Classe, 159, 51-64.

Ziegler, R. 2000. The bats (Chiroptera, Mammalia) from the Late Oligocene fissure fillings Herrlingen 8 and Herrlingen 9 near Ulm (Baden-Württemberg). Senckenbergiana lethaea, 80, 647-683.

Ziegler, R. 2003. Bats (Chiroptera, Mammalia) from Middle Miocene karstic fissure fillings of Petersbuch near Eichstätt, Southern Franconian Alb (Bavaria). Geobios, 36, 447-490; doi: 10.1016/S0016-6995(03)00043-3. 